\section{Identification of tuberculosis infection and sociodemographic risk among children who come into household contact with tuberculosis in Medan, Indonesia}

\section{Fazidah A. Siregar, Lita Sri Andayani,} Mhd. Makmur Sinaga

Faculty of Public Health, Universitas Sumatera Utara, Medan, Indonesia

\begin{abstract}
Although the incidence of tuberculosis (TB) in Medan remains high, cases of TB infection among children who come into household contact with adult TB patients is still low (5.4\%). The purpose of the study was to investigate the proportion of TB infection among children in the households of adult TB patients and to identify risk factors for TB infection in this population. This study was an unmatched case control study with a total of 86 study participants and a case:control ratio of $1: 1$. Tuberculosis skin tests and assessment with TB scoring for children were performed to determine TB infection. Data were analyzed using simple and multiple logistic regressions. The results showed positive tuberculin tests in 17 of the 43 children who had household contact with TB $(39.5 \%)$. It can be concluded that the proportion of tuberculosis infection among children in households where they have contact with adult TB patients is higher than before. Therefore, it is recommended to identify children at high risk for TB and improve TB control program to minimize the risk factors.
\end{abstract}

\section{Introduction}

Tuberculosis (TB) is a leading cause of morbidity and mortality worldwide. The World Health Organization (WHO) reported 10.4 million people were infected with tuberculosis, with 1.7 million deaths, in 2016. The majority of TB cases $(75 \%)$ are found in developing countries. ${ }^{1}$ Indonesia is ranked second highest for TB cases among 30 high burden countries worldwide, and the incidence of TB cases has increased annually. ${ }^{2}$ North Sumatera Province, where Medan is located, is ranked fifth for TB cases in Indonesia. Medan is an endemic area with a high incidence of tuberculosis. ${ }^{3}$ Currently, the number of new TB cases is increasing; however, discovery of TB cases among children is still low. ${ }^{4}$

Persons living in the household with a tuberculosis patient have a high risk of becoming infected and developing tuberculosis, particularly if their immune defenses are impaired. ${ }^{5}$ Children are a group vulnerable to becoming infected with Mycobacterium tuberculosis. Some research shows that the prevalence of TB infection in children living with adult TB patients was higher than in children in the general population. Certain conditions play roles in TB transmission, such as proximity to TB patients, younger age, nutritional status and living in poorly ventilated rooms. ${ }^{6}$

TB in children is both important as a health problem and also reflects the effectiveness of TB control programs. Children are typically infected with TB by adults with TB living around them. Children can also represent a source of new TB infection in adults, increasing of TB in adults in the future. ${ }^{3}$ Furthermore, children are at higher risk of severe forms of tuberculosis, such as military TB and tuberculous meningitis.?

The Centers for Disease Control and Prevention recommends contact investigation to identify and test all close contacts of tuberculosis patients. However, this is rarely done in developing countries.

In the last two years, TB cases in Medan have increased and the number of children in affected households was high. However, discovery of TB cases in children is still low. This study aims to identify tuberculosis infection and sociodemographic risk among children in household contact with tuberculosis cases in Medan.

\section{Materials and Methods}

Study design and targeted population

This was unmatched case control study. Study conducted from May to July, 2018 on samples of cases and controls were recruited from six health facilities. The sample consisted of 43 children in households with TB cases and 43 children without household contact with TB cases. Therefore, the total number of study recruits was 86 at a case: control ratio of 1:1. All respondents were asked to give informed consent for study participation.

\section{Data collection procedure}

Initially, a signed informed consent was asked and then the tuberculin test skin and assessment with the TB scoring system for children was performed to determine tuberculosis infection in children. The Mantoux skin test was performed by injecting $0.1 \mathrm{~mL}$ of 5 tuberculin units (TU) of purified protein derivative (PPD) intrader-
Correspondence: Fazidah Aguslina Siregar, Department of Epidemiology, Public Health Faculty, Universitas Sumatera Utara, University street no 21, Medan, 20155, Indonesia.

Tel : +62.61.8213221, Fax: +62.61 .8213221$

E-mail: fazidah@usu.ac.id

Key words: tuberculosis infection, children, households contact, determinants.

Acknowledgments: The author would like to thank Rector of Universitas Sumatera Utara for providing financial support for this research. We extend our grateful to the Head of district health officer and Head of health facility for their assistance. Special thanks to all people who were involved in this study.

Contributions: FAS and LSA participated in the design of study, data analysis, interpretation and drafted the first manuscript. MMS participated in coordination of data collection, data analysis and interpretation. All authors read and approved the first manuscript.

Conflict of interest: The authors declare no potential conflict of interest

Funding: This research is supported by the Indonesian Ministry of Research and Higher Education in 2018, No: 123 / UN5.2.3.1 PPM / KP-DRPM / 2018.

Ethical clearance: Before the study was conducted, human subject approval was obtained from the Universitas Sumatera Utara on March 29, 2018. The study was approved by the Research and Ethics Committee, School of Medical, Universitas Sumatera Utara (Reference code number 166/III/KPEK FK USU- RSUP HAM 2018).

Conference presentation: part of this paper was presented at the $3^{\text {rd }}$ International Symposium of Public Health, 2018 October 31 - November 1, Universitas Airlangga, Surabaya, Indonesia

Dedication: the article is dedicated to Faculty of Public Health, Universitas Sumatera Utara.

Received for publication: 28 July 2019

Revision received: 9 September 2019.

Accepted for publication: 15 October 2019.

This work is licensed under a Creative Commons Attribution NonCommercial 4.0 License (CC BY-NC 4.0).

(C) Copyright: the Author(s), 2019

Licensee PAGEPress, Italy

Journal of Public Health in Africa 2019; 10(s1):1177 doi:10.4081/jphia.2019.1177 
mally into the volar surface of the forearm. The result was read after $48-72$ hours. ${ }^{8}$ Participants were instructed to return back in 48 hours for their test result. The diameter of the induration area was measured across the forearm and recorded in millimeters of induration.

A test with an induration of at least 10 $\mathrm{mm}$ was considered positive. Furthermore, we assessed tuberculosis infection using TB scoring for children. Parameters were assessed using the tuberculosis scoring system for children, including history of household contact with tuberculosis patients, tuberculin skin test, nutritional status, symptoms and signs. A score of 6 or more indicated a positive tuberculosis test. ${ }^{9}$

Data was collected using a structured questionnaire. The questionnaire was involved questions about sociodemographic features such as age, sex, and education, vaccination, nutritional status, ownership of the house, type of house, crowding, house ventilation, exposure to smoke, and habitual opening of windows in the morning.

\section{Statistical analysis}

Data was analyzed using the Statistical Package for Social Science (SPSS Release 22.0 program Inc. Chicago, Illinois, USA). Descriptive analysis of the variables was presented either as frequency distribution or proportion. The sociodemographic risk factors associated with tuberculosis infection in children with household TB contact were determined using simple and multiple logistic regressions.

\section{Ethical consideration}

This study was carried out with approval of the study were obtained from Research and Ethics Committee, School of Medical, University of North Sumatera.

\section{Results}

Of the total respondent, the mean age was 37.29 (9.53) years. A majority of families: had a household member with high school education $(74.4 \%)$; earned income less than 2.5 million (63.8\%); did not own the home where they lived $(51.2 \%)$; stayed in a permanent house $(65.1 \%)$; had high housing density $(68.6 \%)$; habitually did not open windows in the morning $(60.5 \%)$ (Table 1). The 43 children with household contacts with a person with TB were examined using the Mantoux test. Of these, 17 children $(39.5 \%)$ had positive test results. This proportion was higher than previously reported by the District Health Office, which found only $5.4 \%$ of children with household contact testing positive for TB.
Among the 86 children included in this study, the mean age was $5.71( \pm 3.79)$ years. A majority of the children were male (54.7\%), had the BCG vaccination (88.4\%), had normal nutritional status $(84.9 \%)$ and had exposure to smoking (55.8\%) (Table 2).

The results of the simple logistic regression revealed several variables with p-values less than 0.25 , such as: income, habitually opening window in the morning, housing density, child less than five years old, BCG vaccination and exposure to smoke (Table 3). These variables were then included in the multiple logistic regression using the enter method. This revealed three significant variables of sociodemographic risk for tuberculosis infection among children with household tuberculosis contact: age less than 5 years, habitually did not open window in the morning, and crowding (Table 4).

Table 1. Sociodemographic characteristics of respondents.

\begin{tabular}{lcc} 
Characteristic & Frequency & Proportion (\%) \\
Age & $37.29^{*}$ & 9.52 \\
Education Level & & \\
$\quad$ High & 64 & 74.4 \\
$\quad$ Low & 22 & 25.6 \\
\hline $\begin{array}{l}\text { Income } \\
\quad 2.5 \text { million }\end{array}$ & 38 & 36.2 \\
$\quad<2.5$ million & 67 & 63.8 \\
Ownership of house & & \\
$\quad$ Own & 42 & 48.8 \\
$\quad$ Not own & 44 & 51.2 \\
\hline House type & & 65.1 \\
$\quad$ Permanent & 56 & 34.9 \\
$\quad$ Semi-permanent & 30 & \\
Habitual opening the window in the morning & & 60.5 \\
$\quad$ Yes & 52 & 39.5 \\
$\quad$ No & 34 & 31.4 \\
\hline Crowding & & 68.6 \\
$\quad \leq 2$ person/room & 27 & \\
$\quad>2$ person/room & 58 & \\
\hline
\end{tabular}

*Mean (SD).

Table 2. Characteristics of children.

\begin{tabular}{lcc} 
Characteristic & Frequency & Proportion (\%) \\
Age & $5.71^{*}$ & 3.79 \\
Sex & 47 & 39 \\
$\quad$ Male & 54.7 & 45.3 \\
$\quad$ Female & & \\
BCG immunization status & 76 & 88.4 \\
$\quad$ Yes & 10 & 11.6 \\
$\quad$ No & & \\
Nutritional status & 73 & 84.9 \\
$\quad$ Good & 13 & 15.1 \\
$\quad$ Bad & & 55.8 \\
\hline Exposure to indoor smoke & 48 & 44.2 \\
$\quad$ Yes & 38 & \\
$\quad$ No & & \\
\hline
\end{tabular}

*Mean (SD).

\section{Discussion}

Tuberculosis infection was identified in children from 4 months to 14 years old in Medan. The proportion of tuberculosis occurred in children less than 5 years old. This study found that children aged less than 5 years have a higher risk of tuberculosis infection than those more than 5 years old. This result was consistent with findings from Guwatudde et al. in a study in Kampala, Uganda, that found that younger age (less than five years) was associated with increased risk of TB infection. ${ }^{10}$ Young people are more susceptible to tuberculosis infection especially if they are not immunized and have poor nutritional status. Children less than 5 years old are more susceptible to health problems related to an immature immune system. Some previous infection was $39.5 \%$ and most cases 
studies revealed that illiteracy, proximity with the index case, exposure to smoke, household crowding, and dwelling in slum are associated with tuberculosis infection in household contacts. ${ }^{11,12}$ Likewise, a study in India by Singh found tuberculosis infection in 95 of 281 contacts and determined that younger age, malnutrition, absence of $B C G$ vaccination and exposure to smoke contributed to tuberculosis infection in children. ${ }^{13}$

Overcrowded housing conditions will influence the risk of infection in a child with contact with TB cases. Proximity has the potential to increase exposure to infectious droplet nuclei when family members infected with TB are talking, coughing and sneezing. Thus, proximity created by overcrowding contributes to tuberculosis infection among susceptible people such as children with household contact. In this study, crowding is a significant factor for tuberculosis infection in children with household contact. Children who live in crowded housing had a risk of tuberculosis that was 5.730 times greater than children who did not live in crowded housing. This finding was consistent with the findings of Gayawali et al (2012) in Nepal that household crowding is a significant factor for tuberculosis among children with household contact. ${ }^{11}$ Tornee et al (2004) in Thailand found that people living in crowded households have a risk of tuberculosis 2.63 times higher than people who did not live in crowded households. ${ }^{14}$ Lienhardt et al (2003)) in Gambia, West Africa, found that proximity to tuberculosis patients and housing density are significant factors for tuberculosis infection among children in household contact. ${ }^{15}$ Baker et al researched New Zealand and also found that housing density was a significant factor for tuberculosis incidence. ${ }^{16}$ A study by Walakandou in Kandao Hospital, Menado Indonesia, showed that population in a house (overcrowded) was associated with tuberculosis among children with household contact. ${ }^{17}$ Karim et al (2012) in Bangladesh similarly found that crowding is a risk factor related to tuberculosis infection in children. ${ }^{18}$

The environment and sanitation of the housing play roles in disease transmission. Opening windows in the morning and during the day is necessary to maintain the quality of air and humidity in the house. Inadequate ventilation will cause the humidity in the air to increase, and this creates a good medium for pathogenic bacteria, such as the tuberculosis bacteria, to grow and cause disease. This could increase the population being exposed to TB infection. Gustafson et al (2004) found that crowding and poor quality of housing are associated with tuberculosis incidence in sub-Saharan African communities. ${ }^{19}$ In this study, children who live in a household that did not open windows have a risk of tuberculosis 4.452 times greater than children live in houses with opening windows. A study in Pakistan found that poor ventilation was associated with tuberculosis infection. ${ }^{20}$ Lygizos et al., in study in South Africa, found that opening windows and doors made a significant improvement in ventilation and air change in an hour that had an impact on reducing transmission risk of tuberculosis to $9.6 \%{ }^{21}$ Likewise, Wood et al. (2010), in a study in South Africa, found that increased room ventilation reduced transmission risk, and thereby reduce the probability of tuberculosis infection. ${ }^{22}$

\section{Conclusions}

This study found that the proportion of tuberculosis infection among children in household contact with an adult tuberculosis patient is high. Tuberculosis infection in

Table 3. Factors associated with tuberculosis infection among children in household contact with tuberculosis determined using simple logistic regression.

\begin{tabular}{|c|c|c|c|c|}
\hline Variable & Children with household contact & Children without household contact & Crude OR (95\% CI) & p-value \\
\hline $\begin{array}{l}\text { Age } \\
\qquad 5 \text { years } \\
<5 \text { years }\end{array}$ & $\begin{array}{l}26(60.5 \%) \\
17(39.5 \%)\end{array}$ & $\begin{array}{l}20(46.5 \%) \\
23(39.5 \%)\end{array}$ & $\begin{array}{c}1.757 \\
(1.338: 4.132)\end{array}$ & 0.196 \\
\hline $\begin{array}{l}\text { Income } \\
\quad \geq 2,5 \text { million } \\
<2,5 \text { million }\end{array}$ & $\begin{array}{l}19(44,2 \%) \\
24(55.9 \%)\end{array}$ & $\begin{array}{l}27(62,8 \%) \\
16(37.2 \%)\end{array}$ & $\begin{array}{c}1.760 \\
(0.618 ; 4.358)\end{array}$ & 0.238 \\
\hline $\begin{array}{l}\text { Immunization } \\
\text { Yes } \\
\text { No }\end{array}$ & $\begin{array}{l}35(81.4 \%) \\
8(18.6 \%)\end{array}$ & $\begin{array}{c}41(95,3 \%) \\
2(4.7 \%)\end{array}$ & $\begin{array}{c}4.086 \\
(0.933: 25.531)\end{array}$ & 0.061 \\
\hline $\begin{array}{l}\text { Crowding } \\
\leq 2 \text { person/room } \\
>2 \text { person/room }\end{array}$ & $\begin{array}{c}8(18.6 \%) \\
35(81.4 \%)\end{array}$ & $\begin{array}{l}19(44.2 \%) \\
24(55.8 \%)\end{array}$ & $\begin{array}{c}5.464 \\
(1.355: 7.190)\end{array}$ & 0.013 \\
\hline $\begin{array}{l}\text { Exposure of smoke } \\
\text { Yes } \\
\text { No }\end{array}$ & $\begin{array}{l}29(67.4 \%) \\
14(32.6 \%)\end{array}$ & $\begin{array}{l}19(44.2 \%) \\
24(55.8 \%)\end{array}$ & $\begin{array}{c}2.617 \\
(1.088: 6.289)\end{array}$ & 0.032 \\
\hline $\begin{array}{l}\text { Habitual opening of } \\
\text { Yes } \\
\text { No }\end{array}$ & $\begin{array}{l}19(44.2 \%) \\
24(55.8 \%)\end{array}$ & $\begin{array}{l}33(76.7 \%) \\
10(23.7 \%)\end{array}$ & $\begin{array}{c}4.168 \\
(1.647: 10.553)\end{array}$ & 0.003 \\
\hline
\end{tabular}

Table 4. Factors associated with tuberculosis infection among children in household contact with tuberculosis determined using multiple logistic regression.

\begin{tabular}{lcc} 
Variable & Adjusted OR (95 \% CI) & p-value \\
Age & $2.849(1.000: 8.130)$ & 0.050 \\
Crowding & $5.730(1.776: 18.488)$ & 0.003 \\
\hline Habitual opening of window & $4.452(1.652: 12.198)$ & 0.004 \\
\hline
\end{tabular}


children was influenced by younger age, crowding, and habitually not opening windows. It is therefore recommended that children who are living in households with tuberculosis patients be identified to investigate the high risk of tuberculosis in children and to design improved control strategies based on identified risk factors.

\section{References}

1. World Health Organization (WHO). Global Tuberculosis Report 2016. Available from: http:/www.who.int/tb/ publications/global_report/en/. Accessed on: 1 December 2017.

2. World Health Organization (WHO). Global Tuberculosis Report 2015. Available from: http://www.who.int/tb/ publications/global_report/en/.2016. Accessed on: 2 December 2017.

3. Ministry of Health of Indonesia. Indonesian Health Profile. Jakarta: Ministry of Health of Indonesia; 2016.

4. Medan District Health Office. Tuberculosis case report in Medan. Medan: Health Department; 2015.

5. Zellweger JP. Tuberculosis in households of index patients: is there another way to control tuberculosis. Int J Tuberc Lung Dis. 2002;6:181-2.

6. Newton SM, Brent AJ, Anderson S, et al. Paediatric tuberculosis. Lancet Infect Dis. 2008;8:498-510.

7. Walls T, Shingadia D. Global epidemiology of paediatric tuberculosis. J Infect. 2004;48(1):13-22.

8. American Thoracic Society. Diagnostic standards and classification of tubercu- losis in adults and children. Am J Respir Crit Care Med. 2000;161:1376-95.

9. Ministry of Health of Indonesia. Technical guidelines for management of pediatric tuberculosis. Jakarta: Ministry of Health of Indonesia; 2016.

10. Guwatudde D, Nakakeeto M, JonesLopez EC, et al. Tuberculosis in household contacts of infectious cases in Kampala, Uganda. Am J Epi. 2003;158(9):887-898.

11. Gayawali N, Gurung R, Poudyal N, et al. Prevalence of tuberculosis in households contact of sputum smear cases and associated with sociodemographic risk factors. Nepal Med Coll J. 2012;14(4):303-307.

12. Triasih R, Rutherford M, Lestari $\mathrm{T}$, et al. Contact investigation of children exposed to tuberculosis in South East Asia: a systematic review. J Trop Med. 2012. Available from: http://dx.doi.org/10.1155/2012/301808. Accessed on: 10 August 2018.

13. Singh M, Mynak ML, Kumar L, et al. Prevalence and risk factors for transmission of infection among children in household contact with adults having pulmonary tuberculosis. Arch Dis Child. 2005;90(6):624-628.

14. Tornee S, Kaewkungwal J, Fungladda W, et al. Risk factors for tuberculosis infection among household contacts in Bangkok, Thailand. Southeast Asian J Trop Med Pub Health. 2004;35(2):375383.

15. Lienhardt C, Sillah J, Fielding K. et al. Risk factors for tuberculosis infection in children in contact with infectious tuberculosis cases in the Gambia, West
Africa. Pediatrics 2003;111(5):608-614.

16. Baker M, Das D, Venugopal K, et al.. Tuberculosis associated with household crowding in a developed country. J Epi \& Comm Health 2008;62(8):715-721.

17. Walakandou L, Umboh A, Wahani A. The occurrence and is factor of tuberculosis in children with close contact to adult lung tuberculosis. Paediatrica Indonesia 2010;50(4):233-238.

18. Karim MR, Rahman MA, Mamun SA, et al. S. Risk factors of childhood tuberculosis: a case control study from rural Bangladesh. WHO South-East Asia J Pub Health. 2012;1(1):76.

19. Gustafson P, Gomes VF, Vieira CS, et al. Tuberculosis in Bissau: incidence and risk factors in an urban community in sub-Saharan Africa. Int J Epi. 2004; 33(1):163-172.

20. Khaliq A, Khan IA. Akhtar MW, et al. Environmental risk factors and social determinant of Pulmonary Tuberculosis in Pakistan. Epidemiology Open Access 2015;5(3):1-9.

21. Lygizos M, Shenoi SV, Brooks RP, et al. Natural ventilation reduces high TB transmission risk in traditional homes in rural KwaZulu-Natal, South Africa. BMC I Dis. 2013;13(1):300.

22. Wood R, Johnstone-Robertson S, Uys P, et al. Tuberculosis transmission to young children in a South African community: modeling household and community infection risks. Clin. Infect Dis. 2010;51(4):401-408. 